\title{
Investigation of caprine arthritis-encephalitis virus in Sudan using competitive enzyme-linked immunosorbent assay
}

\author{
Abdelghafar M. Elfahal ${ }^{1}$, Mohammed O. Hussien ${ }^{1}$, Khalid A. Enan ${ }^{1}$, Khalid M. Taha ${ }^{2}$, Diaeldin A. Salih ${ }^{3}$,
} Rajaa H. Halfawi ${ }^{4}$, Zakia A. Mohammed ${ }^{5}$ and Abdelrahim M. El-Hussein ${ }^{6}$

1. Central Laboratory, Ministry of Science and Technology (MST), P.O. Box 7099, Khartoum, Sudan; 2. Atbara Veterinary Research Laboratory (AVRL), P.O. Box 121, Atbara, Sudan; 3. Kassala Veterinary Research Laboratory (KVRL), Kassala, Sudan; 4. Ministry of Animal Resources, Fisheries and Range, Khartoum, Sudan;

5. Veterinary Research Institute, Animal Resources Research Corporation,Soba, Khartoum, Sudan; 6. Animal Resources Research Corporation, P.O. Box 8067 (Al-Amarat), Khartoum, Sudan

Corresponding author: Abdelghafar Mohamed Elfahal, email: ghafra45@gmail.com

Received: 13-12-2012, Revised: 28-01-2013, Accepted: 01-02-2013, Published online: 10-06-2013

How to cite this article: Elfahal AM, Hussien MO, Enan KA, Taha KM, Salih DA, Halfawi RH, Mohammed ZA and El-Hussein AM (2013) Investigation of caprine arthritis-encephalitis virus in the Sudan using competitive enzyme linked immunosorbent assay, Vet World 6(8): 558-562, doi:10.5455/vetworld.2013.558-562

\begin{abstract}
Aim: This seroprevalence study was carried out to detect anti Caprine Arthritis-Encephalitis Virus (CAEV) antibodies in goat sera in five States in Sudan during 2009 and 2010.

Materials and Methods: In this study, 432 sera samples collected from five States in Sudan were screened for anti-CAEV antibodies using a commercially available competitive ELISA(cELISA) kit.

Results: Out of 432 samples, 25 (5.8\%) tested positive using ELISA. The highest prevalence was recorded in El-Gazira State (19\%), whereas the prevalence was $10.7 \%$ in Kassala State, $0.92 \%$ in Khartoum State and no samples tested positive from Northern and River Nile States.

Conclusion: Our findings revealed that the disease had spread to other states, apart from its previously known prevalence in Khartoum, in Sudan. Our results call for better control and quarantine measures on imports of live animals into Sudan for genetic improvement programs. Further epizootiological investigations on CAEV in goats and Maedi Visna Virus in sheep at a national level are also needed to carefully monitor and prevent its spread and also to determine its impact on the economy of Sudan.
\end{abstract}

Keywords: caprine arthritis-encephalitis virus, cELISA, goat, small ruminant lentiviruses, Sudan

\section{Introduction}

Small ruminant lentiviruses (SRLVs) comprise Caprine Arthritis-Encephalitis Virus (CAEV) of goats and Maedi Visna Virus (MVV) of sheep [1]. These retroviruses cause chronic inflammatory disease that affects brain, lungs, joints, and mammary glands causing considerable economic losses and reduced animal production and welfare worldwide [2]. CAEV is an RNA virus that belongs to the genus Lentivirus (family-Retroviridae) that includes non-oncogenic exogenous viruses that cause various diseases of mammals [3]. CAEV was first identified and described in 1980 in the USA [4,5] Transmission of CAEV occurs primarily by ingestion of infected colostrum or milk or through respiratory tract. Horizontal transmission has been registered as a result of close contact, even in animals maintain on pasture [6], but whether or not vertical transmission occurs is still unclear [7]. Viral transmission between goats and sheep has been reported [8, 9]. Recent molecular epidemiological studies have shown that the two viruses (CAEV and $\mathrm{MVV}$ ) represent a spectrum of variants that infect both sheep and goats, respectively. Some variants are restricted to either sheep or goats (classical MVV and

This article is an open access article licensed under the terms of the Creative Commons Attribution License (http://creativecommons. org/licenses/by/2.0) which permits unrestricted use, distribution and reproduction in any medium, provided the work is properly cited.
CAEV strains), but it has been clearly demonstrated that cross-species infection occurs naturally with other variants [10].

Following infection, animals produce anti-viral antibodies, although seroconversion may occur any time requiring few weeks to several months [11]. The primary cells infected in vivo are monocytes and macrophages, with the bone marrow serving as a reservoir for the infection [12]. Virus is disseminated to the target tissues via the blood stream by localizing within the monocytes.

Diagnosis of SRLV infections can be made based on clinical signs. However, this is often not feasible because only a small proportion of the infected animals exhibit clear clinical signs. Disease is rarely observed before the age of two years except in the case of kids of goats where encephalitis can become evident within few months of infection [13]. However, the period from infection to the development of symptoms (latency period) often ranges from several months to years. Moreover, because of the low viral load in vivo, isolation of the virus is an inefficient method for the accurate diagnosis of CAEV infection. The World Organization for Animal Health (OIE) therefore recommends that the most efficient method for diagnosing CAEV infections is by antibody detection using serological testing, such as the agar gel immunodiffusion (AGID) test and enzyme-linked immuno- 
Table-1. Seropositivity to CAEV antibodies in goats detected by cELISA from different states in Sudan

\begin{tabular}{lcccc}
\hline States & No. of samples & No. of positives & Prevalence rate (\%) & True prevalence (\%) \\
\hline El-Gazira & 58 & 11 & 19 & 18.4 \\
Kassala & 122 & 13 & 10.7 & 10.2 \\
The Northern & 30 & 0 & 00.0 & 00.0 \\
River Nile & 113 & 0 & 00.0 & 00.0 \\
Khartoum & 109 & 1 & 0.92 & 0.42 \\
Total & 432 & 25 & 5.8 & 5.3 \\
\hline
\end{tabular}

Table-2. Seropositivity to CAEV infection in goats breeds detected by cELISA from different states in Sudan

\begin{tabular}{lcccc}
\hline State & Breed & Sample & No. of positives & $\%$ of positives \\
\hline El-Gazira & Nubian & 24 & 0 & 00.0 \\
& Shami & 34 & 11 & 32.4 \\
Kartoum & Nubian & 60 & 0 & 00.0 \\
& Saanen Cross & 49 & 1 & 2.00 \\
Kassala & Nubian & 30 & 0 & 00.0 \\
& Shami & 92 & 13 & 14.1 \\
River Nile & Nubian & 21 & 0 & 00.0 \\
& Saanen Cross & 92 & 0 & 00.0 \\
The Northern & Nubian & 30 & 0 & 00.0 \\
Total & & 432 & 25 & 5.8 \\
\hline
\end{tabular}

sorbent assay (ELISA) rather than depending on the virus isolation techniques or clinical observations $[3,14]$.

Until recently there was no solid evidence that CAEV infection represents a threat to small ruminants in Sudan. However, a recent study [15], documented serious health problems confined to only Saanen breed of goats that were imported for genetic improvement. These problems included arthritis, mastitis and pneumonia in adult goats and encephalitis in kids. However, no data are available regarding the status of CAEV infection in states other than Khartoum and in other breeds of goats.

Thus, the goal of the present study was to determine the seroprevalence of CAEV infection among goats in other regions of Sudan and among other breeds of goats. We strongly believe that significant findings from our study will contribute to designing effective strategies for preventing, controlling and/or eradicating CAEV in goats in Sudan.

\section{Materials and Methods}

Ethical approval: The investigation was carried out in compliance with the animal welfare code in Sudan.

Sample collection: 432 samples collected from five States (Khartoum, El-Gazira, Kassala, River Nile and Northern) were assessed for CAEV antibodies using cELISA. All animals that were sampled were apparently healthy except for the shami breed; sampled from El-Gazira State which was suffering from conditions such as arthritis, mastitis, pox and fever. The sampled animals were from small flocks that were reared exclusively for dairy purposes under intensive management systems.

The breeds of goats tested were Shami (126), Nubian (156) and Saanen crossbreed (150). Blood samples for serum were collected, during July 2009 and October 2010 , from the jugular vein $(5 \mathrm{~mL}$ without EDTA). Serum was separated and stored at $-20^{\circ} \mathrm{C}$ until further use.
ELISA technique: ELISA was performed using competitive ELISA kit (VMRD, United Kingdom) according to the manufacturer's instructions to detect antibodies against the CAEV envelope glycoprotein, gp135. The test is based on the principle of competitive ELISA in which serum antibody to CAEV in the sample inhibits the binding of horseradish peroxidase (HRP)-labeled CAEV-specific monoclonal antibody to CAEV antigen coated to the plates. Binding of the HRP-labeled monoclonal antibody conjugate is detected by the addition of enzyme substrate and quantified by subsequent color product development. Weak color development due to inhibition of the monoclonal antibody binding to the antigen coated to the plates indicates the presence of CAEV antibodies in the sample sera. The degree of inhibition is expressed as percent inhibition (PI) and is calculated as follows: Calculation of percent inhibition (PI):

$\mathrm{PI}=100-[($ sample Optical Density X100)/(Mean negative Control O.D)]

The cutoff value of antibody PI is $\geq 35$ i.e. all samples which have antibody PI $\geq 35$ are considered positive.

Adjustment of the true prevalence: The sensitivity of this cELISA was $100 \%$ while the specificity was $96.4 \%$ [16]. Rogan and Gladen [17] estimator $\left(\mathrm{P}_{\mathrm{RG}}\right)$ was used to covert the apparent prevalence values to true prevalence values as follows; $\mathrm{PRG}=\mathrm{AP}+\mathrm{Sp}-1 / \mathrm{Se}+\mathrm{Sp}-1$

Where AP denotes apparent prevalence, Sp denotes specificity, and Se denotes sensitivity.

\section{Results}

Out of 432 samples, 25 (5.8\%) tested positive for CAEV antibodies using ELISA. The highest prevalence was recorded in El-Gazira State (19\%), whereas the prevalence was $10.7 \%$ in Kassala State, $0.92 \%$ in Khartoum State, and no antibodies were detected in samples collected from Northern and River 
Table-3. CAEV Seropositivity in goat breeds detected by cELISA

\begin{tabular}{lccc}
\hline Breed & Sample & No. of positives & \% of positives \\
\hline Shami & 126 & 24 & 19 \\
Nubian & 156 & 0 & 0 \\
Saanen, cross-bred & 150 & 1 & 0.7 \\
Total & 432 & 25 & 5.8 \\
\hline
\end{tabular}

Nile states (Table-1).

After the adjustment for test misclassification, the true overall prevalence of the CAEV in this study was $5.3 \%$, while in El-Gazira, Kassla and Khartoum States it was $18.4 \%, 10.2 \%$ and $0.42 \%$, respectively.

Regarding the breeds of the sampled goats, 24 $(19 \%)$ out of 126 samples from Shami breed were found positive and one sample from Saanen crossbreed was positive $(0.92 \%)$, while all the samples from indigenous goat breeds were negative (Table 2 and 3 ).

\section{Discussion}

Earlier surveys in Africa documented the evidence for SRLVs infections in Kenya [18], Morocco [19], Nigeria [20], Mozambique [21] and Algeria [22]. An interesting factor that was common to these reports is that all these countries imported animals from Europe which facilitated the introduction and spread of the disease. This highlights the fact that the spread of SRLVs occurred predominantly via importation of animals $[22,23]$. Further evidence for such a mode of spread of the infection comes from previous studied which showed that in Japan [24] and Mexico [25], CAEV was found in goats that were imported for their genetic improvement programs. However, animals that carry the virus may not show any clinical signs because of a delayed seroconversion. Such serological latency may often require several months [26] or years before seroconversion becomes evident or may never occur at all, which is a prominent feature of SRLV infections $[11,27,28,29]$. Animals may also fail to develop antibody levels that can be detected by commonly used serology tests $[11,30]$.

Recently in Sudan, the concerned veterinary authorities started regulating the imports of goats for genetic improvement programmes by allowing only the import/introduction of animals that were brought from flocks certified free of the disease. However, as discussed above, animals that carry the virus may not show any clinical signs complicating the task of the officials involved in the import and control programmes. Indeed, the disease was confirmed in Sudan in 2010 in goat herds in Khartoum State [15], where all the positive reactors were either imported from other countries or were crossbred.

Goats that tested positive by cELISA were from El-Gazira (19\%), Kassala (10.7\%), and Khartoum $(0.92 \%)$ states and no antibodies were detected in goats from Northern and River Nile States. All reactors in ElGazira and Kassala States belong to the Shami breed of goats. The high seropositivity of antibodies in ElGazira State (19\%) clearly indicated an importation of infected animals into the state. The same reasoning may also apply to a high percentage of the infections found in Shami breed in Kassala (10.7\%) which were recently imported from Cyprus.

As mentioned earlier, only a few of the infected animals develop clinical signs and therefore the risks posed by the disease are usually underestimated by the owners and veterinary clinicians. Almost all veterinarians we interacted with did not hear nor had no knowledge about this disease. On the other hand, the negative results in the River Nile state in purebred saanen and their crossbred lines may indicate the presence of disease-free animals, due to the recent rigorous regulations imposed by the veterinary authorities of that state. However, because of delayed seroconversion, some of the infected animals may test positive in the future. On the other hand, our finding that the positive samples were detected in Khartoum state in Saanen crossbred goats is in agreement with the results obtained by Elfahal et al. [15] who reported the prevalence of the disease in the same ecotype.

It is worth noting that all animals that were confirmed as positives with CAEV were maintained under a closed management system which may have contributed to the horizontal transmission when the infected animals are introduced; a notion supported by the findings of East et al. [31] and Gufler [6, 32]. Fortunately, no CAEV infections have so far been detected in the indigenous Nubian goats in Sudan, clearly indicating that the risk of infection is largely associated with importing infected animals. Majority of the indigenous goats are reared on open natural pastures where chances of horizontal transmission are minimal. However, this situation may be altered if the management system is shifted to a closed system; often to cater to the requirements of exports to neighboring countries.

Significant findings from our study clearly suggest that proper control measures are needed to prevent future occurrences of clinical outbreaks caused by CAEV infections in goat herds of Sudan. Furthermore, we strongly believe that the information obtained on seroprevalence of CAEV infection in this study is an important first step towards the establishment of effective control and/or eradication programmes in the future.

\section{Conclusion}

Key findings from our study clearly showed that CAEV infection exists in other states in Sudan besides Khartoum, albeit currently being restricted to imported breeds and their crosses. Furthermore, based on our findings, we strongly believe that there is an urgent need for detailed epizootiological investigations on 
CAEV and Maedi Visna virus at the national level to monitor its spread and determine its impact on the economy of Sudan. We also recommend that better control and quarantine measures be implemented while importing animals for genetic improvement.

\section{Authors' contributions}

AME, MOH and KAE carried out the ELISA assays and drafted the manuscript. KMT, DAS, RHH collected the samples and analyzed the data. ZAM and AME contributed to the conception and design of the study and thoroughly revised the manuscript. All authors read and approved the final manuscript.

\section{Acknowledgments}

The authors are thankful to Central Laboratory, Ministry of Science and Technology, Khartoum, Sudan for funding this research.

\section{Competing interests}

The authors declare that they have no competing interests.

\section{References}

1. Olech, M., Rachid, N., Croisé, B., Kuzmak, J. and Valas, S, (2012) Genetic and antigenic characterization of small ruminant lentiviruses circulating in Poland. Virus. Res., 163: 528-536.

2. Brinkhof, J. M. A., Moll, L. D., Van Maanen, C. and Houwers, D. J., (2010) Use of serology and polymerase chain reaction for the rapid eradication of small ruminant lentivirus infections from a sheep flock: A case report. Res. Vet. Sci., 88: 41-43.

3. Konishi, M., Nagura, Y., Takei, N., Fujita, M., Hayashi, K., Tsukiok, M., Yamamoto,T., Kameyama, K., Sentsui, H. and Murakami, K.,(2011) Combined eradication strategy for CAE in a dairy goat farm in Japan. Small. Rum. Res.,99: 65-71.

4. Crawford, T. B., Adams, D. S., Cheevers, W. P. and Cork, L. C. (1980a) Chronic arthritis in goats caused by a retrovirus. Science., 207: 997-999.

5. Crawford, T. B., Adams, D. S., Sande, R. D., Gorham, J. R. and Henson, J. B. (1980b) The connective tissue component of the caprine arthritis encephalitis syndrome. Am. J. Pathol., $100(2): 443-450$.

6. Gufler, H. (2004) CAEV: clinical and serological findings and the economical losses in a goat herd of "Passeirer Goat". Tier"arztl. Praxis., 32: 263-268.

7. Fieni, F., Rowe, J., van Hoosear, K., Burucoa, C., Oppenheim, S., Anderson, G., Murray, J. and BonDurant, R. (2003) Presence of caprine arthritis encephalitis virus (CAEV) proviral DNA in genital tract tissues of superovulated dairy goat does. Theriogenology., 59: 1515-1523.

8. Pisoni, G., Bertoni, G., Boettcher, P., Moroni, P. (2004) Phylogenetic analysis of the gag region encoding the matrix protein of small ruminant lentiviruses: comparative analysis and molecular epidemiological applications. Vet. Res., 116: $159-167$.

9. Shah, C. A., Boni, J., Huder, J. B., Vogt, H.R.,Muhlherr, J., Zanoni, R., Miserez, R., Lutz, H. and Schupbach, J. (2004) Phylogenetic analysis and reclassification of caprine and ovine lentiviruses based on 104 new isolates: evidence for regular sheep-to-goat transmission andworld-wide propagation through livestock trade. Virol., 319: 12-26.

10. Blacklaws, B. A. (2012) Small ruminant lentiviruses: Immunopathogenesis of visna-maedi and caprine arthritis and encephalitis virus. Comp. Immunol. Microbiol. Infect. Dis. 35: 259-269.

11. Eltahir, Y. M., Dovas, C. I., Papanastassopoulou, M., Koumbati, M., Giadinis, N., Verghese-Nikolakaki, S. and
Koptopoulos, G. (2006) Development of a semi-nested PCR using degenerate primers for the generic detection of small ruminant lentiviruses proviral DNA. J. Virol., 135: 240-246.

12. Gendelman, H. E., Narayan, O., Molineaux, S., Clements, J. E. and Ghotbi, Z. (1985) Slow, persistent replication of lentiviruses: Role of tissue macrophages and macrophage precursors in bone marrow. Proc. Natl. Acad. Sci., USA 82: 7086-7090.

13. Narayan, O. and Cork, L.(1985) Lentiviral diseases of sheep and goats: chronic pneumonia leukoencephalitis and arthritis. Rev. Infect. Dis., 7: 89-98.

14. Knowles, D. and Herrmann, L. M. (2008) Caprine arthritis -encephalitis \& Maedi-Visna. In: OIE Biological Standards Commission (Ed.), Manual of Diagnostic Tests and Vaccines for Terrestrial Animals (Mammals, Birds, and Bees), vol. 2, 6 th edition. World organization for Animal Health (OIE), pp. 983-991, Chapter 2. 7.3/4.

15. Elfahal, A. M., Zakia, A. M. and El Hussien, A. M. (2010) First report of Caprine Arthritis Encephalitis virus in Khartoum State- Sudan. J. Anim. Vet. Adv., 9(4):736-740.

16. Herrmann, L. M., Cheevers, W. P., McGuire, T. C., Adams, D. S., Hutton, M. M., Gavin, W. G. and Knowles1, D. P. (2003) Competitive-Inhibition Enzyme-Linked Immunosorbent Assay for Detection of Serum Antibodies to Caprine Arthritis-Encephalitis Virus: Diagnostic Tool for Successful Eradication. Clin. Diagn. Lab. Immunol., 10:2267-271.

17. Rogan, W. J. and Gladen. B.(1978) Estimating prevalence from the results of a screening test. Am. J. Epidemiol., 107: 71-76.

18. Wandera, J. G.(1970) Progressive interstitial pneumonia of sheep in Kenya. Vet. Rec., 86: 434-438.

19. Mahin, L., Chadli, M. and Houwers, D. J. (1984) A preliminary report on the occurrence of maedi-visna in sheep in Morocco. Vet. Q., 6: 104.

20. Belino, E. D. and Ezeifeka, G. O. (1984) Maedi-Visna antibodies in sheep and goats in Nigeria. Vet. Rec., 114: 570.

21. Pereira, C. L., Baule, C. Costa, R. and Langa, A. (1989) Occurrence of caprine arthritis-encephalitis in Mozambique. Trop. Anim. Hlth. Prod., 21:237-238.

22. De Boer, G. F., Terpstra, C. Houwers, D. G. and Hendrisks, J. (1979) Studies in the epidemiology of maedi-visna in sheep. Res. Vet. Sci., 26: 202-208.

23. Adams, D. S., Grawford, T. B., Klevjer-Anderson, P. (1980) A pathologentic study of the early connective tissue lesions of caprine arthritis-encephalitis. Am. J. Pathol., 99: 257-278.

24. Konishi, M., Tsuduku S., Haritani, M. Murakami, K. Tsuboi, T. Kobayashi, C. Yoshikawa, K. Kimura, K. M. and Sentsui, H. (2004) An epidemic of caprine arthritis-encephalitis in Japan: isolation of the virus. J. Vet. Med. Sci., 66:911-917.

25. Torres-Acosta, J. F. J., Gutierrez-Ruiz, E. J., Schmidt, A., Evans, J., Babington, J., Bearman, K., Fordham, T. Brownlie, T., Schroer, S. Camara-G, E. and Lightesy, J. (2003) Serological survey of caprine arthritis-encephalitis virus in 83 goat herds of Yucatan, Mexico. Small Rum. Res., 49: 207211.

26. Brinkhof, J. M. A., Houwers, D. J., Moll, L., Dercksen, D. and van Maanen, C. (2012) Diagnostic performance of ELISA and PCR in identifying SRLV-infected sheep and goats using serum, plasma and milk samples and in early detection of infection in dairy flocks through bulk milk testing. Vet. Microbiol., 142: 193-198.

27. Houwers, D. J. and Van Der Molen, E. J. (1987) A five-year serological survey of natural transmission of maedi-visna virus in a flock of sheep, completed with post mortem investigation. J. Vet. Med., 34: 421-431.

28. Johnson, L. K., Meyer, A. L., Zink, M. C. (1992) Detection of ovine lentivirus in seronegative sheep by in situ hybridization, PCR and co cultivation with susceptible cells. Clin. Immunol. Immunopath., 65: 254-260.

29. Wagter, L. H. A., Jansen, A., Bleumink-Pluym, N. M. C., Lenstra, J. A. and Houwers, D. J. (1998) PCR detection of lentiviral gag segment DNA in the white blood cells of sheep 
and goats. Vet. Res. Commun., 22: 355-362.

30. Krassnig. R. and Schuller W.(1998) Continuation of the observation and serological investigation of a maedi-visna virus infected sheep flock from Januray 1990 to June 1996. Dtsch. Tieraztl. Wschr., 105: 50-53.

31. East, N. E., Rowe, J. D., Dahlberg, J. E., Theilen, G. H. and Pedersen, N.C.(1993) Modes of transmission of caprine arthritis-encephalitis virus infection. Small Rumin. Res., 10: 251-262.

32. Brinkhof, J. M. A., Moll, L. D., Van Maanen, C. and Houwers, D. J., (2010) Use of serology and polymerase chain reaction for the rapid eradication of small ruminant lentivirus infections from a sheep flock: A case report. Res. Vet. Sci., 88: 41-43.

$* * * * * * * *$ 